Supporting Information

ACS Sustainable Chemistry \& Engineering

\title{
Ionic liquids with natural origin component: a path to new plant
}

\section{protection products}

Joanna Feder-Kubis, ${ }^{*}{ }^{\dagger}$ Patrycja Czerwoniec, ${ }^{\ddagger, \S}$ Piotr Lewandowski, ${ }^{\ddagger, \S}$ Henryk Pospieszny ${ }^{\ddagger}, \|$ and Marcin Smiglak ${ }^{\ddagger}, \perp$

\footnotetext{
+ Wrocław University of Science and Technology, Faculty of Chemistry, Wybrzeże Wyspiańskiego 27, 50-370 Wrocław, Poland

${ }^{\ddagger}$ Poznan Science and Technology Park, Adam Mickiewicz University Foundation, ul. Rubież 46, 61-612

Poznań, Poland

${ }^{\S}$ Faculty of Chemistry, Adam Mickiewicz University, ul. Umultowska 89b, 61-614 Poznań, Poland

" Institute of Plant Protection - National Research Institute, ul. W. Wegorka 20, 60-318 Poznań, Poland

${ }^{\perp}$ Innosil Sp. z o.o., ul. Rubież 46, 61-612 Poznań, Poland
}

Number of pages: 14

Number of figures: 1

Number of tables: 1

1. Synthesis of the precursors of chiral ionic liquids (2-6) S2

2. Chiral ionic liquids with benzo[1.2.3]thiadiazole-7-carboxylate anion - purification $\quad \mathrm{S} 2$

3. Table S1. Abbreviation, yield, cationic active substance content, empirical formula, S3 elementary analysis for the precursors, 3-alkyl-1-[(1R,2S,5R)-(-)menthoxymethyl]imidazolium chlorides

4. Materials used for synthesis and analysis $\quad$ S4

5. Analytical methods S4-S6

6. Biological tests S6-S8

7. Fig. S1. MIC and MBC/MFC values for selected a) Gram-positive bacteria, b) Gram- S9 negative bacteria, c) yeasts.

8. NMR and elemental data of obtained compounds $\quad$ S10-S13

9. References $\quad$ S14 


\section{Synthesis of the precursors of chiral ionic liquids (2-6)}

As a quaternary agent, chloromethyl $(1 R, 2 S, 5 R)-(-)$-menthyl ether (1) was used, which was prepared as the first compound in the entire process. ${ }^{1}$ This excellent reagent for quaternization was synthesized by chloromethylation of $(1 R, 2 S, 5 R)-(-)$-menthol under anhydrous conditions and reduced temperature (not higher than $5-10{ }^{\circ} \mathrm{C}$ ). Next quaternization reaction was conducted, using freshly distilled chloromethyl $(1 R, 2 S, 5 R)-(-)$-menthyl ether $\left(91-92{ }^{\circ} \mathrm{C}\right.$ at $\left.1.3 \mathrm{mbar}\right)$ and appropriate type of the selected amine, which was distilled or crystallized before use. The following Menschutkin reaction was carried out in anhydrous hexane. The process occurs very fast or even immediately (depending on the type of the amine used, Table S1) and affords a very high product yield. Importantly, the quaternization reaction does not require any energy input. On the contrary, due to the high reactivity of such ethers, certain attention should be paid to avoid increasing temperature during the process.

\section{Purification of chiral ionic liquids with benzo[1.2.3]thiadiazole-7-carboxylate anion}

Each product was washed several times (approximately 3-5) with distilled water in order to prevent the presence of any impurities, both organic and inorganic. The halide level determined by the $\mathrm{AgNO}_{3}$ test did not shown any positive results, which means that no chlorides $>500 \mathrm{ppm}$ were observed. After evaporation of the solvent, the high purity products were kept under high vacuum (0.3 mmHg) for approx. $3-5$ days at around $50{ }^{\circ} \mathrm{C}$, using a cold trap and an inert gas. 
Table S1 Abbreviation, yield, cationic active substance content, empirical formula, elementary analysis calculation and found for the precursors, 3-alkyl-1-[(1R,2S,5R)-(-)-menthoxymethyl]imidazolium chlorides (2-6)

\begin{tabular}{|c|c|c|c|c|c|c|c|c|}
\hline $\begin{array}{l}\text { Salt } \\
\text { no }\end{array}$ & $\begin{array}{l}\text { Abbreviation } \\
{\left[\mathrm{C}_{\mathrm{n}}-\mathrm{Im}-\mathrm{CH}_{2} \mathrm{OMen}\right][\mathrm{Cl}]}\end{array}$ & $\mathrm{R}$ & $\begin{array}{l}\text { Time of the } \\
\text { reaction } \\
\text { [min] }\end{array}$ & $\begin{array}{l}\text { Yield }^{a, b} \\
{[\%]}\end{array}$ & $\begin{array}{l}\text { Surfactant } \\
\text { content }^{c} \\
{[\%]}\end{array}$ & $\begin{array}{l}\text { Empirical } \\
\text { formula }\end{array}$ & $\begin{array}{l}\text { Elementary analysis } \\
\text { calculation } \\
{[\%]}\end{array}$ & $\begin{array}{l}\text { Elementary analysis found } \\
{[\%]}\end{array}$ \\
\hline 2 & {$\left[\mathrm{C}_{9}-\mathrm{Im}-\mathrm{CH}_{2} \mathrm{OMen}\right][\mathrm{Cl}]$} & $\mathrm{C}_{9} \mathrm{H}_{19}$ & $10-15$ & 97.5 & 99.5 & $\mathrm{C}_{23} \mathrm{H}_{43} \mathrm{OClN}_{2}$ & C 69.225, H 10.86, N 7.02 & C 69.33, H 10.92, N 6.94 \\
\hline 3 & {$\left[\mathrm{C}_{12}-\mathrm{Im}-\mathrm{CH}_{2} \mathrm{OMen}\right][\mathrm{Cl}]$} & $\mathrm{C}_{12} \mathrm{H}_{25}$ & $15-25$ & 97.0 & 98.6 & $\mathrm{C}_{26} \mathrm{H}_{49} \mathrm{OClN}_{2}$ & C 70.79, H 11.20, N 6.35 & C 70.85, H 11.33, N 6.24 \\
\hline 4 & {$\left[\mathrm{Im}-\left(\mathrm{CH}_{2} \mathrm{OMen}\right)_{2}\right][\mathrm{Cl}]$} & $\begin{array}{l}\text { Sym- } \\
\text { menthol }\end{array}$ & $5-10$ & 93.5 & 98.7 & $\mathrm{C}_{25} \mathrm{H}_{45} \mathrm{ClN}_{2} \mathrm{O}_{2}$ & C 68.07, H 10.28 N 6.35 & C 68.13, H 10.32, N 6.27 \\
\hline 5 & {$\left[\mathrm{C}_{9}-\mathrm{Am}-\mathrm{CH}_{2} \mathrm{OMen}\right][\mathrm{Cl}]$} & $\mathrm{C}_{9} \mathrm{H}_{19}$ & immediately & 98.5 & 99.2 & $\mathrm{C}_{22} \mathrm{H}_{46} \mathrm{NOCl}$ & C 70.26, H 12.33, N 3.72 & C 70.17, H 12.45, N 3.86 \\
\hline 6 & {$\left[\mathrm{C}_{12}-\mathrm{Am}-\mathrm{CH}_{2} \mathrm{OMen}\right][\mathrm{Cl}]$} & $\mathrm{C}_{12} \mathrm{H}_{25}$ & immediately & 98.0 & 98.5 & $\mathrm{C}_{25} \mathrm{H}_{52} \mathrm{CINO}$ & C 71.81, H 12.53, N 3.35 & C 71.86, H 12.45, N 3.37 \\
\hline
\end{tabular}


Materials. The chemicals, (1R,2S,5R)-(-)-menthol (99\%), paraformaldehyde (powder, 95\%), sodium (cubes, contains mineral oil, $99.9 \%$ trace metals basis), imidazole ( $\geq 99 \%), 1$-bromononane (98\%), 1-bromododecane (97\%), dimethylnonylamine (97\%), dodecyldimethylamine (97\%), triethylamine ( $\geq 99 \%$ ), hydrochloric acid (35\%-38\%), sulfuric acid ( $\geq 96 \%$ ), and benzalkonium chloride $(\geq 95 \%)$ were purchased from Merck. The drying agents, such as sodium sulphate (anhydrous, pure) and phosphorus pentoxide (powder, anhydrous, $\geq 98 \%$ ) were provided by Alchem (Gliwice, Poland).

BTH used for further derivatization was extracted from the commercially available BIONTM 50WG (Syngenta) plant protection agent. The BTH extraction method and deprotonation into ionic potassium carboxylate were performed using previously reported materials and methods. ${ }^{2}$

All reagents were dried and purified before use according to common procedures. Solvents were purchased from the commercial suppliers, Sigma-Aldrich and Fluka, and were dried according to standard procedures and stored over molecular sieves. For nuclear magnetic resonance (NMR) analysis, deuterated chloroform $\left(\mathrm{CDCl}_{3}\right)$ purchased from Merck was used. Analytical thin-layer chromatography (TLC) was performed by using Merck-prepared plates (silica gel G 1.05570.0001 on aluminium).

\section{Analytical methods}

In order to minimize contact with air moisture, the studied ILs were kept in Schlenk flasks in a dessicator between each experiment. The samples were then dried for at least $48 \mathrm{~h}$ under vacuum $(\approx 3$ mbar $)$ at $t \approx 50^{\circ} \mathrm{C}$ before each experiment.

Specific rotations. Specific rotations at $578 \mathrm{~nm}$ at $1000 \mathrm{mbar}$ were measured using an Optical Activity Ltd. Model AA-5 automatic polarimeter at $25^{\circ} \mathrm{C}$ (resolution $\pm 0.01^{\circ}$, reproducibility \pm 
$0.01^{\circ}$, accuracy $\pm 0.01^{\circ}$, temperature probe measurement accuracy $\pm 0.1^{\circ} \mathrm{C}$ with four results for each measurement).

Refractive index. The refractive index at $25^{\circ} \mathrm{C}$ at $1000 \mathrm{mbar}, \mathrm{n}_{D}{ }^{25}$ for the studied liquid salts with benzo[1.2.3]thiadiazole-7-carboxylate anion was measured by means of an Automatic Digital Refractometer RX-5000 $\alpha$ (Atago company) with an uncertainty of $\pm 0.00004 \mathrm{n}_{\mathrm{D}}$ units and temperature probe measurement accuracy $\pm 0.1^{\circ} \mathrm{C}$. Before each measurement, the refractive index of pure distilled water was measured and compared with its literature value $\left(\mathrm{n}_{\mathrm{D}}{ }^{25}=1.33300\right)$.

In order to minimize contact with air moisture, the studied ILs were kept in Schlenk flasks in a dessicator between each experiment.

The cationic active substance content. The active cationic content was assayed using a direct two-phase titration: (i) for salts with molecular mass lower than $500 \mathrm{~g} / \mathrm{mol}(\mathbf{2}-\mathbf{6})$ the procedure European Standard 2010: EN ISO 2871-2 $2^{3}$ was used and (ii) salts with higher molecular mass (812) were analysed according to the EN ISO $2871-1$ technique. ${ }^{4}$ The method is based on titration in the water-chloroform system (in case of salts completely soluble in water, 2-6) or in the system consisting of water-methanol-chloroform for compounds with limited solubility in water (8-12) using proper salts. Standard sodium dodecylsulphate(VI) solution with the presence of the mixed indicator diimidium bromide indicator (CAS: 518-67-2) were used for determining cationic active substances, and sulfan blue indicator (CAS: 129-17-9) was used for determining active anionic substances.

Analyses of active cationic content were conducted for all of the obtained chiral salts; the results are given in Table 1 for benzo[1.2.3]thiadiazole-7-carboxylate salts (8-12) and in ESI (Table S1) for their chloride precursors (2-6). 


\section{Thermal analysis}

Differential Scanning Calorimetry (DSC). Melting points were determined using the differential scanning calorimetry (DSC) method in the STARe System (Mettler Toledo). Samples were between 6 and $15 \mathrm{mg}$, closed in aluminium pans, and stored under argon atmosphere (flow rate: 20 $\mathrm{mL} / \mathrm{min}$ ). During the first heating cycle, the heating ramp was set from $25^{\circ} \mathrm{C}$ to $50{ }^{\circ} \mathrm{C}$ (except for compound 10, which was heated to $110^{\circ} \mathrm{C}$ ) with a heating rate of $10^{\circ} \mathrm{C} / \mathrm{min}$. At this temperature, samples were held for a $5 \mathrm{~min}$ isotherm. In the next step, samples were cooled from $50{ }^{\circ} \mathrm{C}$ (or 110 ${ }^{\circ} \mathrm{C}$ ) to $-50{ }^{\circ} \mathrm{C}$ with a cooling rate of $10{ }^{\circ} \mathrm{C} / \mathrm{min}$, and then remained under constant temperature conditions for $5 \mathrm{~min}$ at $-50{ }^{\circ} \mathrm{C}$. The last step involved heating the sample from $-50{ }^{\circ} \mathrm{C}$ to $50{ }^{\circ} \mathrm{C}$ (or $110^{\circ} \mathrm{C}$ in case of salt $\mathbf{1 0}$ ) with a heating rate of $10^{\circ} \mathrm{C} / \mathrm{min}$.

Thermogravimetric analysis (TGA). Thermogravimetric analysis was performed using a TGA Q50 Texas Instrument. Samples between 5 and $10 \mathrm{mg}$ were heated from $25^{\circ} \mathrm{C}$ to $500{ }^{\circ} \mathrm{C}$ with a heating rate of $10^{\circ} \mathrm{C} / \mathrm{min}$ with a $10 \mathrm{~min}$ isotherm at $75^{\circ} \mathrm{C}$ under nitrogen atmosphere. This isotherm step was intended to help remove any remaining water and possible volatile impurities present in the samples. Temperatures reported for all materials' decomposition profiles were established as the onset temperature for decomposition of the first $5 \%$ of the sample $\left(\mathrm{T}_{5 \% \text { onset }}\right)$ and later as the regular onset temperature for decomposition $\left(\mathrm{T}_{\text {onset }}\right)$, either for the whole sample or for each of the consecutive steps in the multistep decomposition.

\section{Biological tests}

Antimicrobial tests. The antimicrobial activity of the newly formed chiral ILs (8-12) was determined using the 96-well microdilution assay according to the Clinical and Laboratory Standards Institute M27-A $3^{5}$ and M07-A9 ${ }^{6}$ using Gram-positive bacterial strains (Staphylococcus aureus ATCC 6538, Staphylococcus epidermidis ATCC 14990, Enterococcus faecium ATCC 6057, Enterococcus faecalis ATCC 29212, Enterococcus hirae ATCC 10541, and Bacillus subtilis 
ATCC 6633) and Gram-negative bacterial strains (Escherichia coli ATCC 10536, Serratia marcescens ATCC 274, Proteus hauseri ATCC 13315, Klebsiella pneumoniae ATCC 700603, and Pseudomonas aeruginosa ATCC 15442), yeast-like fungi (Candida albicans ATCC 10231, Candida glabrata ATCC 90030, Candida krusei ATCC 6258, Candida parapsilosis ATCC 22019, Candida tropicalis ATCC 750, Candida guilliermondii ATCC 6260, and Cryptococcus neoformans ATCC 14116). Standard strains were supplied by American Type Culture Collection (ATCC). Bacterial strains were cultured in Mueller Hinton broth (MHB) at $37{ }^{\circ} \mathrm{C}$ and Candida spp. in RPMI-1640 medium at $37^{\circ} \mathrm{C}$. Briefly, sterile stock solutions of tested compounds (8-12) in $\mathrm{H}_{2} \mathrm{O}_{\mathrm{dd}}+2.5 \%$ (v/v) MeOH were two-fold serially diluted in MHB or RPMI-1640 media to obtain a final concentration range of $0.0625-64 \mu \mathrm{g} / \mathrm{mL}$ on microdilution sterile plates (Sarstedt, Stare Babice, Poland). All tested conditions were prepared at least in three independent repetitions. The plates were cultivated for $24 \mathrm{~h}$ at $37^{\circ} \mathrm{C}$ (bacteria) or $48 \mathrm{~h}$ at $37^{\circ} \mathrm{C}$ (Candida spp.). Afterwards, OD490 was measured using the microplate reader, ASYS UVM 340 (Biogenet, Józefów, Poland). The concentration that resulted in $\geq 80 \%$ growth inhibition was determined as the minimal inhibitory concentration (MIC80; $\mu \mathrm{g} / \mathrm{mL}$ ). An equal volume from each well was then re-plated into Mueller Hinton agar (MHA) (bacteria) or Sabouraud agar (fungi) and incubated for $48 \mathrm{~h}$ at $37^{\circ} \mathrm{C}$. The lowest concentration that resulted in non-visible growth was determined as minimum bactericidal or fungicidal concentration (MBC or MFC).

Figure S1a, Figure S1b and Figure S1c present the microbiological effectiveness of all the tested ILs (8-12) and of BAC observed for Gram-positive bacteria, Gram-negative bacteria and yeasts, respectively.

SAR induction properties evaluation. In the following experiments, plants of N. tabacum var. Xanthi in the stage of three developed leaves were sprayed with $10-15 \mathrm{ml}$ or watered with $50 \mathrm{ml}$ solution of tested compound in water at the same concentration as active substance (20 mg/l) and 
the control with the same distilled water that was used for the preparation of solutions. Seven days later, the treated leaves were infected mechanically with TMV. After the next 4 to 5 days, local necrotic spots, resulting from a viral infection, were counted and compared between the number of spots on the leaves treated with salts (8-12) and distilled water (control). A reduction in the number of necrotic spots on the leaves treated with salts, in comparison with the control, demonstrated viral infection via induction of plant resistance through the use of tested compound. Moreover, aside from the reduction in the number of local necrotic spots, in tobacco plants treated with salts, reduction in the size of local necrotic spots formed on leaves was observed.

Phytotoxicity. Phytotoxicity tests were performed on two plant models: N. tabacum var. Xanthi and Raphanus sativus. In first variation of the experiment, the N. tabacum var. Xanthi plants were watered with distilled water solutions $(50 \mathrm{ml})$ containing the active substance at a concentration of $50 \mathrm{mg} / \mathrm{l}$. Several days after treatment, the visual effects of the tested compounds on the plants were analysed. In the second phytotoxic experiment, the Raphanus sativus seeds were grown on a pan in examined solutions of tested substance at concentrations of 10 and $20 \mathrm{mg} / \mathrm{L}$ at a temperature 22 ${ }^{\circ} \mathrm{C}$. After five days, sprouts were dried and weighed. 
a) Gram-positive bacteria

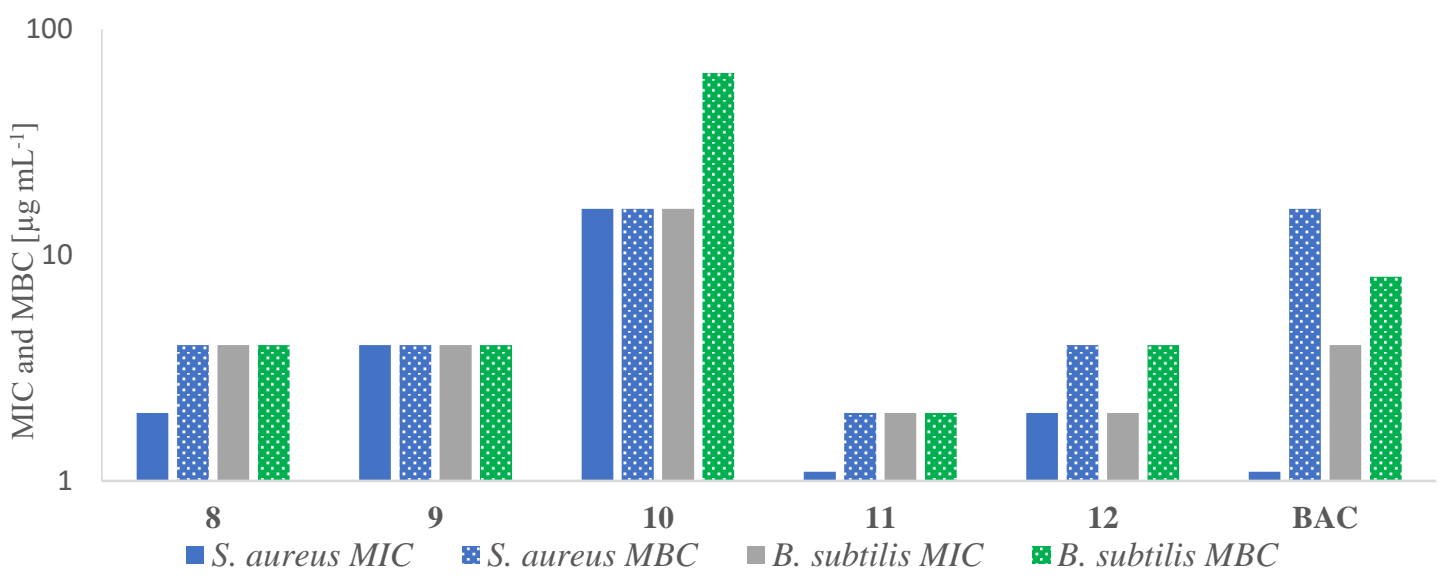

b) Gram-negative bacteria

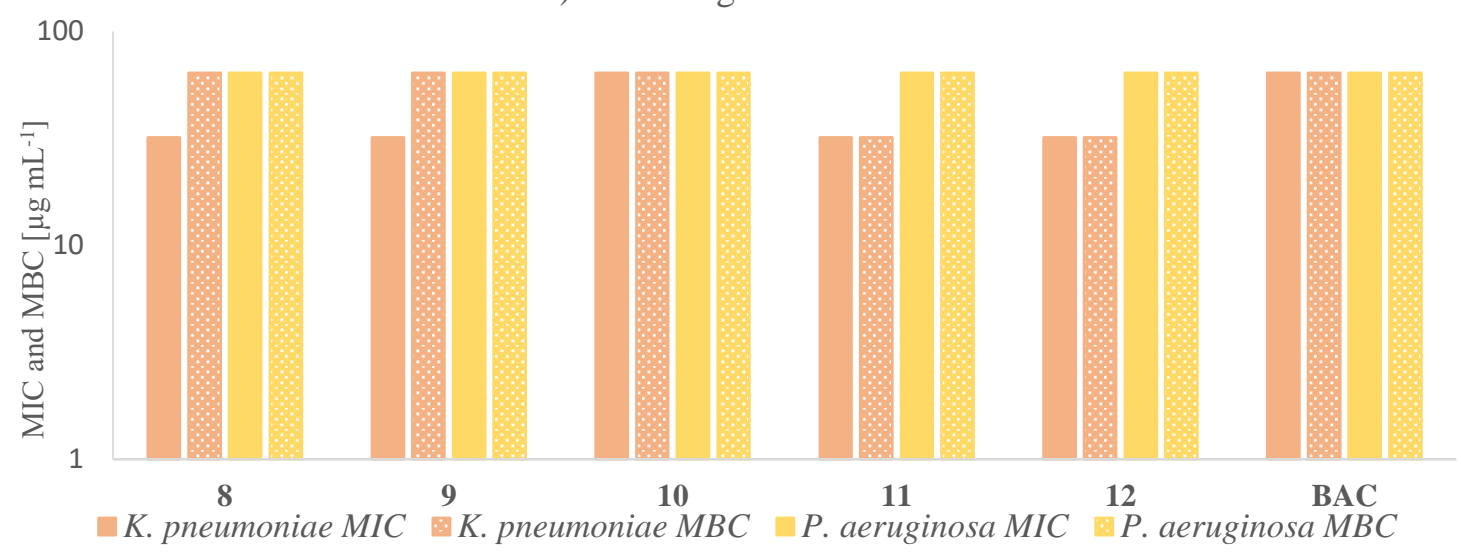

c) Yeast

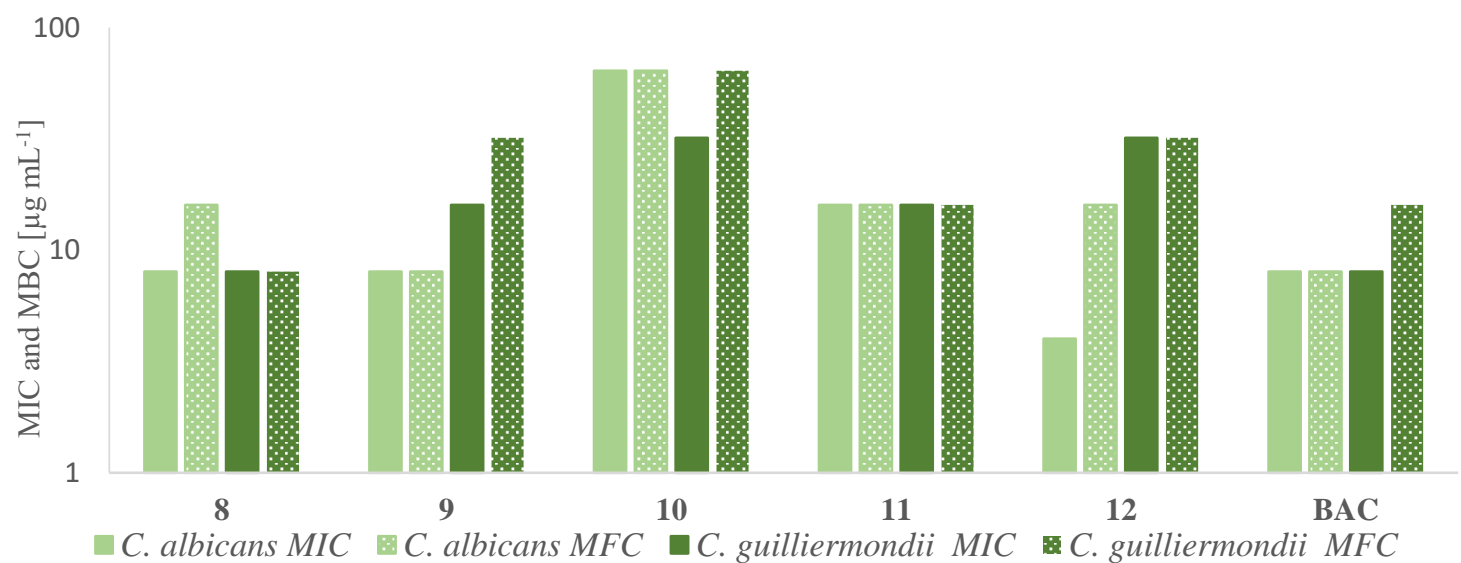

Figure S1. MIC and MBC/MFC values for selected a) Gram-positive bacteria, b) Gramnegative bacteria, c) yeasts. 


\section{NMR and elemental data of obtained compounds}

1-[(1R,2S,5R)-(-)-Menthoxymethyl]-3-nonylimidazolium $\quad$ benzo[1.2.3]thiadiazole-7carboxylate [C9-Im-CH2OMen] [BTHCOO] (8): Yield: 99.9\%, 0.0099 mol, 5.422 g.

${ }^{1} \mathrm{H}$ NMR $\left(400 \mathrm{MHz}, \mathrm{CDCl}_{3}, 25{ }^{\circ} \mathrm{C}\right) \delta[\mathrm{ppm}]=0.40\left(\mathrm{~d}, J=6.8 \mathrm{~Hz}, 3 \mathrm{H}\right.$, men: $\left.\underline{\mathrm{CH}}_{3}-\mathrm{CH}\right), 0.67(\mathrm{~d}, J$ $=6.4 \mathrm{~Hz}, 3 \mathrm{H}$, men: $\left.\underline{\mathrm{CH}_{3}}-\mathrm{CH}\right), 0.76-0.875\left(\mathrm{~m}, 9 \mathrm{H}\right.$, men $6 \mathrm{H}:$ cyc $3 \mathrm{H}, \mathrm{CH}_{3}$, im. alkyl 3H: $\left.\mathrm{CH}_{3}\right), 1.14-$ 1.255 (m, 14H, men 2H, im. alkyl 12H: 6xCH$), 1.49-1.52(\mathrm{~m}, 2 \mathrm{H}, \mathrm{men}), 1.85-1.89$ (m, 3H, men: $\mathrm{CH}_{3}-\underline{\mathrm{CH}}$, im. alkyl 2H: N-CH $\left.2-\underline{\mathrm{CH}_{2}}\right), 1.97-2.00(\mathrm{~m}, 1 \mathrm{H}, \mathrm{men}), 3.32\left(\mathrm{td}, J^{1,3}=10,4 \mathrm{~Hz}, J^{1,2}=4,4\right.$ $\mathrm{Hz}, 1 \mathrm{H}$, men $\underline{\mathrm{CH}}-\mathrm{O}), 4.305$ (t, $J=7.2 \mathrm{~Hz}, 2 \mathrm{H}$, im. alkyl $\left.2 \mathrm{H}: \mathrm{N}-\underline{\mathrm{CH}_{2}}\right), 5.63$ and $5.99(\mathrm{~d}, J=10,6$ $\mathrm{Hz}, J=10,8 \mathrm{~Hz}, 2 \mathrm{H}, \mathrm{AB}$ system, N- $\underline{\mathrm{CH}}_{2}-\mathrm{O}$ ), 7.19 (s, 1H, im.), 7.35 (s, 1H, im.), 7.63-7.675 (m, 1H, anion), 8.33-8.35 (m, 1H, anion), 8.61-8.63 (m, 1H, anion), 11.33 (s, 1H, im.);

${ }^{13} \mathrm{C} \mathrm{NMR}\left(100 \mathrm{MHz}, \mathrm{CDCl}_{3}, 25{ }^{\circ} \mathrm{C}\right) \delta[\mathrm{ppm}]=14.16$ (im. alkyl $\left.3 \mathrm{H}: \mathrm{CH}_{3}\right), 15.56$ (men: $\left.\underline{\mathrm{CH}}_{3}-\mathrm{CH}\right)$, 20.98 (men: $\mathrm{CH}_{3}$ ), 22.02 (men: $\underline{\mathrm{CH}_{3}}-\mathrm{CH}$ ), 22.66 (im. alkyl $\mathrm{CH}_{2}$ ), 22.79 (men), 25.50 (men: $\mathrm{CH}_{3}-$ $\underline{\mathrm{CH}}$ ), 26.29 (im. alkyl $\mathrm{CH}_{2}$ ), 28.98 (im. alkyl $\mathrm{CH}_{2}$ ), 29.12 (im. alkyl $\mathrm{CH}_{2}$ ), 29.34 (im. alkyl $\mathrm{CH}_{2}$ ), 30.29 (im. alkyl $\mathrm{CH}_{2}$ ), 31.14 (men), 31.80 (im. alkyl $\mathrm{CH}_{2}$ ), 34.01 (men), 40.28 (men), 47.71 (men),

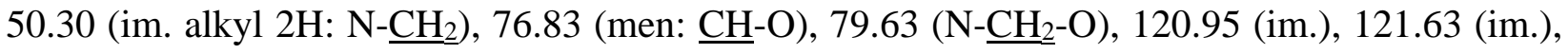
125.60 (anion), 127.11 (anion), 129.37 (anion), 130.35 (anion), 139.61 (im.), 140.85 (anion), 158.31 (anion), 169.43 (anion).

Elemental analysis: calc. (\%) for $\mathrm{C}_{30} \mathrm{H}_{46} \mathrm{O}_{3} \mathrm{~N}_{4} \mathrm{~S}$ (542.78): C 66.38, H 8.54, N 10.32, found: C 66.29, H 8.68, N 10.36.

\section{3-Dodecyl-1-[(1R,2S,5R)-(-)-menthoxymethyl]imidazolium}

benzo[1.2.3]thiadiazole-7carboxylate [C12-Im-CH2OMen] [BTHCOO] (9): Yield: 98.5\%, 0.00985 mol, $5.761 \mathrm{~g}$. ${ }^{1} \mathrm{H}$ NMR $\left(400 \mathrm{MHz}, \mathrm{CDCl}_{3}, 25^{\circ} \mathrm{C}\right) \delta[\mathrm{ppm}]=0.40\left(\mathrm{~d}, J=6.8 \mathrm{~Hz}, 3 \mathrm{H}\right.$, men: $\left.\underline{\mathrm{CH}}_{3}-\mathrm{CH}\right), 0.685-0.84$ (m, 12H, men 9H: $\mathrm{CH}_{3}-\mathrm{CH}, \mathrm{CH}_{3}$, cyc 3H, im. alkyl 3H: $\left.\mathrm{CH}_{3}\right), 1.14-1.265$ (m, 20H, men 2H, im. alkyl 18H: 6xCH ), 1.57-1.61 (m, 2H, men), 1.84-1.88 (m, 3H, men: $\mathrm{CH}_{3}-\underline{\mathrm{CH}}$, im. alkyl 2H: $\mathrm{CH}_{2}$ ), 
1.97-2.00 (m, 1H, men), $3.31\left(\mathrm{td}, J^{1,3}=10,4 \mathrm{~Hz}, J^{1,2}=4,0 \mathrm{~Hz}, 1 \mathrm{H}\right.$, men $\left.\underline{\mathrm{CH}}-\mathrm{O}\right), 4.30(\mathrm{t}, J=7.2 \mathrm{~Hz}$, 2H, im. alkyl 2H: $\left.\mathrm{N}-\underline{\mathrm{CH}_{2}}\right), 5.63$ and $5.96\left(\mathrm{~d}, J=10,8 \mathrm{~Hz}, J=10,8 \mathrm{~Hz}, 2 \mathrm{H}, \mathrm{AB}\right.$ system, $\left.\mathrm{N}-\underline{\mathrm{CH}}_{2}-\mathrm{O}\right)$, 7.20 (s, 1H, im.), 7.35 (t, $J=1,2 \mathrm{~Hz}, J=1,6 \mathrm{~Hz}, 1 \mathrm{H}, \mathrm{im}$.), 7.64-7.68 (m, 1H, anion), 8.34-8.36 (m, 1H, anion), 8.63-8.65 (m, 1H, anion), 11.11 (s, 1H, im.);

${ }^{13} \mathrm{C} \mathrm{NMR}\left(100 \mathrm{MHz}, \mathrm{CDCl}_{3}, 25{ }^{\circ} \mathrm{C}\right) \delta[\mathrm{ppm}]=14.21$ (im. alkyl 3H: $\left.\mathrm{CH}_{3}\right), 15.57$ (men: $\left.\underline{\mathrm{CH}_{3}}-\mathrm{CH}\right)$, 20.97 (men: $\mathrm{CH}_{3}$ ), 22.04 (men: $\underline{\mathrm{CH}_{3}}-\mathrm{CH}$ ), 22.74 (im. alkyl $\mathrm{CH}_{2}$ ), 22.80 (men), 25.50 (men: $\mathrm{CH}_{3}-$ $\underline{\mathrm{CH}}$ ), 26.29 (im. alkyl $\mathrm{CH}_{2}$ ), 28.99 (im. alkyl $\mathrm{CH}_{2}$ ), 29.385 (im. alkyl 2xCH 2 ), 29.51 (im. alkyl 2xCH ), 29.615 (im. alkyl $\mathrm{CH}_{2}$ ), 30.29 (im. alkyl $\mathrm{CH}_{2}$ ), 31.15 (men), 31.81 (im. alkyl $\mathrm{CH}_{2}$ ), 34.01 (men), 40.30 (men), 47.71 (men), 50.32 (im. alkyl 2H: N- $\underline{\mathrm{CH}}_{2}$ ), 76.82 (men: $\left.\underline{\mathrm{CH}}-\mathrm{O}\right), 79.70$ (N$\left.\underline{\mathrm{CH}_{2}}-\mathrm{O}\right), 121.00$ (im.), 121.67 (im.), 125.97 (anion), 127.15 (anion), 129.56 (anion), 129.60 (anion), 139.21 (im.), 140.78 (anion), 158.39 (anion), 169.25 (anion).

Elemental analysis: calc. (\%) for $\mathrm{C}_{33} \mathrm{H}_{52} \mathrm{O}_{3} \mathrm{~N}_{4} \mathrm{~S}$ (584.86): C 67.77, H 8.96, N 9.58, found: C 67.85, H 9.09, N 9.42.

\section{1,3-Bis-[(1R,2S,5R)-(-)-menthoxymethyl]imidazolium benzo[1.2.3]thiadiazole-7-carboxylate [Im-(CH2OMen)2] [BTHCOO] (10): Yield: 98.0\%, $0.0098 \mathrm{~mol}, 5.731 \mathrm{~g}$.}

${ }^{1} \mathrm{H}$ NMR $\left(400 \mathrm{MHz}, \mathrm{CDCl}_{3}, 25{ }^{\circ} \mathrm{C}\right) \delta[\mathrm{ppm}]=0.46\left(\mathrm{~d}, J=6.0 \mathrm{~Hz}, 4 \mathrm{H}, 2 \mathrm{xmen}: \underline{\mathrm{CH}_{3}}-\mathrm{CH}\right), 0.67-$ 0.90 (m, 18H, 2xmen: $\underline{\mathrm{CH}_{3}}-\mathrm{CH}$, cyc $\left.3 \mathrm{H}, \mathrm{CH}_{3}\right), 1.17-1.25(\mathrm{~m}, 2 \mathrm{H}, 2 \mathrm{xmen}), 1.50-1.61(\mathrm{~m}, 4 \mathrm{H}$, 2xmen), 1.90-2.04 (m, 4H, 2xmen: $\left.\mathrm{CH}_{3}-\underline{\mathrm{CH}}, \mathrm{cyc}\right), 3.30-3.34$ (m, 2H, 2xmen $\left.\underline{\mathrm{CH}}-\mathrm{O}\right), 5.66$ and 5.95 $\left(\mathrm{d}, J=10,4 \mathrm{~Hz}, 2 \mathrm{H}, \mathrm{AB}\right.$ system, $\left.\mathrm{N}-\underline{\mathrm{CH}}_{2}-\mathrm{O}\right), 7.06$ (d, $\left.J=1.2 \mathrm{~Hz}, 1 \mathrm{H}, \mathrm{im}.\right), 7.38$ (d, $J=1.6 \mathrm{~Hz}, 1 \mathrm{H}$, im.), 7.66-7.78 (m, 1H, anion), 8.35-8.39 (m, 1H, anion), 8.655-8.68 (m, 1H, anion), 11.43 (s, 1H, im.);

${ }^{13} \mathrm{C} \mathrm{NMR}\left(100 \mathrm{MHz}, \mathrm{CDCl}_{3}, 25{ }^{\circ} \mathrm{C}\right) \delta[\mathrm{ppm}]=15.71$ (men: $\left.\underline{\mathrm{CH}_{3}}-\mathrm{CH}\right), 20.98$ (men: $\left.\mathrm{CH}_{3}\right), 22.06$ (men: $\underline{\mathrm{CH}}_{3}-\mathrm{CH}$ ), 22.82 (men), 25.50 (men: $\mathrm{CH}_{3}-\underline{\mathrm{CH}}$ ), 31.19 (men), 34.00 (men), 40.23 (men), 47.81 (men), 76.91 (men: $\underline{\mathrm{CH}}-\mathrm{O}), 79.82$ ( $\left.\mathrm{N}-\underline{\mathrm{CH}}_{2}-\mathrm{O}\right), 119.15$ (im.), 121.08 (im.), 126.21 (anion), 
127.16 (anion), 129.13 (anion), 129.71 (anion), 139.43 (im.), 140.75 (anion), 158.44 (anion), 169.28 (anion).

Elemental analysis: calc. (\%) for $\mathrm{C}_{32} \mathrm{H}_{48} \mathrm{O}_{4} \mathrm{~N}_{4} \mathrm{~S}(584,81)$ : C 67.57, H 8.51, N 9.85, found: C 67.64, H 9.04, N 9.70.

[(1R,2S,5R)-(-)-Menthoxymethyl]dimethylnonylammonium

benzo[1.2.3]thiadiazole-7carboxylate [C9-Am-CH2OMen] [BTHCOO] (11): Yield: 99.0\%, 0.0099 mol, $5.146 \mathrm{~g}$. ${ }^{1} \mathrm{H}$ NMR $\left(400 \mathrm{MHz}, \mathrm{CDCl}_{3}, 25{ }^{\circ} \mathrm{C}\right) \delta[\mathrm{ppm}]=0.70\left(\mathrm{~d}, J=6.8 \mathrm{~Hz}, 3 \mathrm{H}\right.$, men: $\left.\underline{\mathrm{CH}_{3}}-\mathrm{CH}\right), 0.75(\mathrm{~d}, J$ $=6.4 \mathrm{~Hz}, 3 \mathrm{H}$, men: $\left.\underline{\mathrm{CH}_{3}}-\mathrm{CH}\right), 0.815-0.90\left(\mathrm{~m}, 9 \mathrm{H}\right.$, men $6 \mathrm{H}:$ cyc $3 \mathrm{H}, \mathrm{CH}_{3}$, am. alkyl $\left.3 \mathrm{H}: \underline{\mathrm{CH}_{3}}-\mathrm{CH}_{2}\right)$, 1.17-1.27 (m, $14 \mathrm{H}$, men $2 \mathrm{H}$, am. alkyl 12H: $\left.6 \mathrm{xCH}_{2}\right), 1.55-1.62(\mathrm{~m}, 4 \mathrm{H}$, men $2 \mathrm{H}$, am. alkyl $2 \mathrm{H}: \mathrm{N}-$ $\left.\mathrm{CH}_{2}-\underline{\mathrm{CH}_{2}}\right), 1.94-2.02$ (m, 2H, men: $\left.\mathrm{CH}_{3}-\underline{\mathrm{CH}}, \mathrm{cyc}\right), 3.30-3.38$ (m, 8H, 2x N-CH $\left.3, \mathrm{~N}-\mathrm{CH}_{2}\right), 3.47$ (td, $J^{1,3}=10,4 \mathrm{~Hz}, J^{1,2}=4,0 \mathrm{~Hz}, 1 \mathrm{H}$, men $\left.\underline{\mathrm{CH}}-\mathrm{O}\right), 4.88$ and $4.94(\mathrm{~d}, J=6.8 \mathrm{~Hz}, 2 \mathrm{H}, \mathrm{AB}$ system, N$\left.\underline{\mathrm{CH}}_{2}-\mathrm{O}\right), 7.61-7.65(\mathrm{~m}, 1 \mathrm{H}$, anion), 8.29-8.31 (m, $1 \mathrm{H}$, anion), 8.57-8.59 (m, $1 \mathrm{H}$, anion);

${ }^{13} \mathrm{C}$ NMR $\left(100 \mathrm{MHz}, \mathrm{CDCl}_{3}, 25{ }^{\circ} \mathrm{C}\right) \delta[\mathrm{ppm}]=14.16\left(\mathrm{am}\right.$. alkyl 3H: $\left.\underline{\mathrm{CH}_{3}}-\mathrm{CH}_{2}\right), 15.93$ (men: $\underline{\mathrm{CH}_{3}}{ }^{-}$ CH), 21.09 (men: $\mathrm{CH}_{3}$ ), 22.01 (men: $\underline{\mathrm{CH}_{3}}-\mathrm{CH}$ ), 22.45 (am. alkyl $\mathrm{CH}_{2}$ ), 22.68 (men), 22.73 (am. alkyl $\mathrm{CH}_{2}$ ), 25.95 (men: $\mathrm{CH}_{3}-\underline{\mathrm{CH}}$ ), 26.37 (am. alkyl $\mathrm{CH}_{2}$ ), 29.19 (am. alkyl 2xCH $\mathrm{x}_{2}$ ), 29.31 (am. alkyl $\mathrm{CH}_{2}$ ), 31.20 (men), 31.80 (am. alkyl $\mathrm{CH}_{2}$ ), 33.96 (men), 40.60 (men), 47.89 ( $\left.\mathrm{N}-\mathrm{CH}_{3}\right), 47.95$

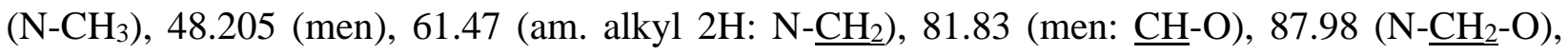
125.00 (anion), 127.06 (anion), 129.01 (anion), 131.70 (anion), 140.94 (anion), 158.18 (anion), 169.13 (anion).

Elemental analysis: calc. (\%) for $\mathrm{C}_{29} \mathrm{H}_{49} \mathrm{O}_{3} \mathrm{~N}_{3} \mathrm{~S}$ (519,78): C 67.01, H 9.50, N 8.08, found: C 67.11, H 9.62, N 7.98. 
Dodecyl[(1R,2S,5R)-(-)-menthoxymethyl]dimethylammonium $\quad$ benzo[1.2.3]thiadiazole-7carboxylate [C12-Am-CH2OMen] [BTHCOO] (12): Yield: 98.0\%, 0.0098 mol, 5.506 g.

${ }^{1} \mathrm{H}$ NMR $\left(400 \mathrm{MHz}, \mathrm{CDCl}_{3}, 25{ }^{\circ} \mathrm{C}\right) \delta[\mathrm{ppm}]=0.70\left(\mathrm{~d}, J=7.2 \mathrm{~Hz}, 3 \mathrm{H}\right.$, men: $\left.\underline{\mathrm{CH}}_{3}-\mathrm{CH}\right), 0.76(\mathrm{~d}, J$ $=6.8 \mathrm{~Hz}, 3 \mathrm{H}$, men: $\left.\underline{\mathrm{CH}_{3}}-\mathrm{CH}\right), 0.84-0.87\left(\mathrm{~m}, 9 \mathrm{H}\right.$, men $6 \mathrm{H}$ : cyc $3 \mathrm{H}, \mathrm{CH}_{3}$, am. alkyl $\left.3 \mathrm{H}: \underline{\mathrm{CH}_{3}}-\mathrm{CH}_{2}\right)$, 1.17-1.315 (m, 20H, men 2H, am. alkyl 18H: 9xCH2), 1.56-1.63 (m, 4H, men 2H, am. alkyl 2H: $\left.\mathrm{N}-\mathrm{CH}_{2}-\mathrm{CH}_{2}\right), 1.94-2.02$ (m, 2H, men: $\mathrm{CH}_{3}-\underline{\mathrm{CH}}$, cyc), 3.30-3.34 (m, 8H, 2x N-CH $\left.3, \mathrm{~N}-\mathrm{CH}_{2}\right), 3.47$ $\left(\mathrm{td}, J^{1,3}=10,8 \mathrm{~Hz}, J^{1,2}=4,4 \mathrm{~Hz}, 1 \mathrm{H}\right.$, men $\left.\underline{\mathrm{CH}}-\mathrm{O}\right), 4.87$ and $4.92(\mathrm{~d}, J=7.2 \mathrm{~Hz}, J=6.8 \mathrm{~Hz}, 2 \mathrm{H}, \mathrm{AB}$ system, $\left.\mathrm{N}-\underline{\mathrm{CH}_{2}}-\mathrm{O}\right), 7.62-7.66(\mathrm{~m}, 1 \mathrm{H}$, anion), 8.31-8.34 (m, 1H, anion), 8.59-8.61 (m, 1H, anion); ${ }^{13} \mathrm{C} \mathrm{NMR}\left(100 \mathrm{MHz}, \mathrm{CDCl}_{3}, 25^{\circ} \mathrm{C}\right) \delta[\mathrm{ppm}]=14.21\left(\mathrm{am}\right.$. alkyl 3H: $\left.\underline{\mathrm{CH}_{3}}-\mathrm{CH}_{2}\right), 15.94$ (men: $\underline{\mathrm{CH}}_{3}{ }^{-}$ CH), 21.09 (men: $\mathrm{CH}_{3}$ ), 22.02 (men: $\underline{\mathrm{CH}}_{3}-\mathrm{CH}$ ), 22.46 (am. alkyl $\mathrm{CH}_{2}$ ), 22.75 (men, am. alkyl $\mathrm{CH}_{2}$ ), 25.945 (men: $\mathrm{CH}_{3}-\underline{\mathrm{CH}}$ ), 26.38 (am. alkyl $\mathrm{CH}_{2}$ ), 29.18 (am. alkyl $\mathrm{CH}_{2}$ ), 29.385 (am. alkyl 2xCH ), 29.49 (am. alkyl CH ), 29.64 (am. alkyl 2xCH ), 31.20 (men), 31.96 (am. alkyl CH 2 ), 33.965 (men), 40.59 (men), $47.90\left(\mathrm{~N}-\mathrm{CH}_{3}\right), 47.975\left(\mathrm{~N}-\mathrm{CH}_{3}\right), 48.205$ (men), 61.458 (am. alkyl 2H: N- $\underline{\mathrm{CH}_{2}}$ ), 81.80

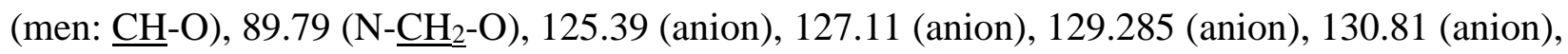
140.86 (anion), 158.26 (anion), 169.11 (anion).

Elemental analysis: calc. (\%) for $\mathrm{C}_{32} \mathrm{H}_{55} \mathrm{O}_{3} \mathrm{~N}_{3} \mathrm{~S}(561,86)$ : C 68.405, H 9.87, N 7.48, found: C 68.31, H 9.95, N 7.92. 


\section{REFERENCES}

1 Pernak, J.; Feder-Kubis, J. Synthesis and properties of chiral ammonium-based ionic liquids Chem. Eur. J., 2005, 11, 4441-4449, DOI 10.1002/chem.200500026.

2 Lewandowski, P.; Kukawka, R.; Pospieszny, H.; Smiglak, M. Bifunctional quaternary ammonium salts based on benzo[1,2,3]thiadiazole-7-carboxylate as plant systemic acquired resistance inducers. New J. Chem., 2014, 38, 1372-1375, DOI 10.1039/C3NJ01613G.

3 EUROPEAN STANDARD 2010: EN ISO 2871-2. Surface active agents. Detergents. Determination of cationic-active matter content. Part 2: Cationic-active matter of low molecular mass (between 200 and 500). Management Centre: Avenue Marnix 17, B1000 Brussels.

4 EUROPEAN STANDARD 2010: EN ISO 2871-1. Surface active agents. Detergents. Determination of cationic-active matter content. Part 1: High-molecular-mass cationicactive matter. Management Centre: Avenue Marnix 17, B-1000 Brussels.

5 Clinical and Laboratory Standards Institute, 2008. Reference Method for Broth Dilution Antifungal Susceptibility Testing of Yeast; Approved Standard - Third Edition. CLI document M27-A3. Wayne, PA.

6 Clinical and Laboratory Standards Institute, 2012. Methods for Dilution Antimicrobial Susceptibility Tests for Bacteria That Grow Aerobically; Approved Standard-Ninth Edition. CLSI document M07-A9. Wayne, PA. 